\title{
Distribution pattern, density and growth of the stout razor clam Tagelus plebeius in a South-west Atlantic estuarine system
}

\author{
BETINA J. LOMOVASKY ${ }^{1}$, THOMAS BREY ${ }^{2,3}$, ANDREAS KLÜGEL ${ }^{4}$ AND OSCAR IRIBARNE ${ }^{1}$ \\ ${ }^{1}$ Laboratorio de Ecología, Instituto de Investigaciones Marinas y Costeras (IIMyC), Consejo Nacional de Investigaciones Científicas y \\ Técnicas (CONICET), Universidad Nacional de Mar del Plata (UNMDP), CC 1260 Correo Central (B76ooWAG), Mar del Plata, \\ Argentina, ${ }^{2}$ Alfred Wegener Institute, Helmholtz Center for Polar and Marine Research, Bremerhaven, Germany, ${ }^{3}$ University \\ Bremen, Bremen, Germany, ${ }^{4}$ University Bremen, Fachbereich 5 - Geosciences, Postfach 3304 40, 28334 Bremen, Germany
}

\begin{abstract}
The population biology of the stout razor clam Tagelus plebeius is poorly understood, despite the species' current wide distribution, and the potential use of its Holocene shell deposits to infer past environmental and ecological conditions. This study investigates distribution and growth pattern of $\mathrm{T}$. plebeius in the south-western Atlantic Mar Chiquita Coastal lagoon $\left(37^{\circ} 32^{\prime} S 57^{\circ} 19^{\prime} \mathrm{W}\right)$, Argentina. The population includes the oldest individuals (up to 27 years) reported so far with shell length up to $77.9 \mathrm{~mm}$. A von Bertalanffy model with $\mathrm{L}_{\infty}=67.60 \mathrm{~mm}(95 \% \mathrm{CI}=64.55 ; 70.64), \mathrm{k}=0.181$ year ${ }^{-1}(C I=$ $0.142 ; 0.218)$, and $\mathrm{t}_{o}=-0.77(C I=-1.46 ;-0.08)$ best described their individual growth for the whole population. The higher density, growth rate $\mathrm{k}, \mathrm{t}_{o}$ and maximum age and lower $\mathrm{L}_{\infty}$ were in the low intertidal rather than in the medium intertidal, but there were no differences in density and age between medium and high intertidal. Given the results and the current knowledge on the effects of different factors influencing this species, we conclude that the distribution pattern and shell growth observed in our study reflect a response to metabolic necessities in combination with a strong influence of biological interactions.
\end{abstract}

Keywords: Tagelus plebeius, razor clam, growth, age, Mar Chiquita Coastal Lagoon

Submitted 4 January 2016; accepted 10 November 2016; first published online 12 December 2016

\section{INTRDDUCTION}

The determination of individual age and growth rate is one of the key parameters for stock assessment (e.g. Lai et al., 1996; Orensanz \& Jamieson, 1998). Growth, production and physiological activity in bivalve species can be affected by abiotic factors such as temperature (e.g. Green, 1973; Jones et al., 1989; Dekker \& Beukema, 1999), substrate characteristics (e.g. Pratt, 1953; Pratt \& Campbell, 1956; Urban, 1998), variations in salinity (e.g. Morton, 1978; Vincent et al., 1994; Kube et al., 1996) and food availability (e.g. Beukema \& Desprez, 1986; Beukema \& Cadée, 1991; Arneri et al., 1998). Moreover, population processes such as density-dependence (e.g. Weinberg, 1998; Dekker \& Beukema, 1999; Gutiérrez \& Defeo, 2003) and interaction processes (trophic and nontrophic such as presence of predators, parasitism, ecological engineers) can also affect growth rate (e.g. Nakaoka, 2000; Beal, 2006; Lomovasky et al., 2006). In this sense, along an intertidal gradient, the effects of environmental stress on shell growth seem to outweigh those of biological interactions at higher zones (Reise, 1998; Gosling, 2003; Cognie et al., 2006), while the relationship is opposite at lower intertidal levels (Bartol et al., 1999; Bologna \& Heck, 1999). Thus, knowledge of the biological characteristics, distribution

Corresponding author:

B.J. Lomovasky

Email: lomovask@mdp.edu.ar patterns, abundance and growth across the intertidal range constitutes additional information for sustainable management of exploited intertidal bivalve populations.

The stout razor clam Tagelus plebeius (Lightfoot, 1786) is a euryhaline species that inhabits tidal flats with cohesive sandy silt sediments along the American Atlantic coast from Cape Cod, Massachusetts $\left(42^{\circ} \mathrm{N}\right.$, USA; Leal, 2002) to the Northern Argentinean Patagonia (San Matías Gulf, $41^{\circ} \mathrm{S}$, Argentina; Olivier et al., 1972a, b). Their shells are ubiquitous in Holocene estuarine deposits of central South America (1340 to 3850-year B.P.; Fasano et al., 1982; Schnack et al., 1982) and are often used as indicators of palaeoenvironmental conditions (see Golfieri et al., 1998; Iribarne \& Botto, 1998; Iribarne et al., 1998; Aguirre \& Farinati, 1999). This suspension-feeding species (Holland \& Dean, 1977a; Arruda et al., 2003) is a deep burrowing species that inhabits permanent burrows (up to $0.70 \mathrm{~m}$ depth) showing vertical movements through each semidiurnal tidal cycle, but not showing intertidal migration (Holland \& Dean, 1977b). Current knowledge of T. plebeius biology and ecology is limited to a few localities in Argentina (Mar Chiquita coastal lagoon: Cledón et al., 2004; Lomovasky et al., 2005, 2006; Addino et al., 2010, 2016; Bahía Blanca estuary: Addino et al., 2015), Brazil (Canal do Calunga, Maceió: Viégas, 1982; São Sebastião: Abrahão \& Amaral, 1999; Arruda et al., 2003; Abrahão et al., 2010; Cachoeira river estuary: Ceuta \& Boehs, 2012; Ceara river estuary: de Farias \& Rocha-Barreira, 2012; Caraguatatuba Bay: da Silva et al., 2015), and the USA (North Inlet estuary, Holland \& Dean, 1977a, b). 
Given the current knowledge about the effects of biological interactions on this species, we expect distinct patterns of individual growth in T. plebeius across an intertidal system. For example the differences in morphometric characteristics related to the presence of the intertidal burrowing crab Neohelice granulata (a co-habiting species, Lomovasky et al., 2006), to parasitism by the gymnophallid metacercariae (Lomovasky et al., 2005; Addino et al., 2010), and to the presence of salt marsh plants Spartina alterniflora (Addino et al., 2015) are important. Given this evidence, we hypothesize that the density pattern and individual growth may respond to metabolic necessities of this species determining differential recruitment and mortality, albeit modulated by trophic (e.g. predation, parasitism, competition) and non-trophic (e.g. ecosystems engineering) biological interactions. Accordingly, we expect highest density and growth rates at the low intertidal level. Thus, the aims of the present study are to evaluate the distribution pattern, density and growth of the stout razor clam T. plebeius across intertidal in Mar Chiquita Coastal Lagoon estuarine system.

\section{MATERIALS AND METHDDS}

\section{Study area, sampling procedure and sediment characteristics}

The study was performed between January 2003 and March 2004 in the Mar Chiquita Coastal Lagoon ( $37^{\circ} 32^{\prime} \mathrm{S} 57^{\circ} 19^{\prime} \mathrm{W}$; Argentina). This is a brackish water area of about $46 \mathrm{~km}^{2}$ with muddy sediments and low tidal amplitude $\left(<_{1} \mathrm{~m}\right.$, Fasano et al., 1982). Sampling was conducted in a tidal flat area located along $3 \mathrm{~km}$ of shoreline from the lagoon inlet at seven different sites (Figure 1). At each site, samples were taken at three tidal levels parallel to the shore with similar



Fig. 1. The seven sampling sites in the Mar Chiquita Coastal Lagoon, Argentina, South-west Atlantic. exposure time: low intertidal level (LIL) $0.40 \mathrm{~m}$ above mean low tide (thereafter amlt), medium intertidal level (MIL) $0.55 \mathrm{~m}$ amlt and high intertidal level (HIL) $0.75 \mathrm{~m}$ amlt.

Five sediment samples (cores of $5 \mathrm{~cm}$ diameter and $35 \mathrm{~cm}$ depth) were collected at each site and tidal level in January 2004. Organic matter content (OMC) of $\sim 10 \mathrm{~g}$ subsamples was determined as the difference between dry weight $\left(80^{\circ} \mathrm{C}\right.$ to constant weight) and the ash weight $\left(450^{\circ} \mathrm{C}\right.$ for $\left.8 \mathrm{~h}\right)$. Grain size frequency distribution was obtained by sieving a dried $400 \mathrm{~g}$ subsample through a series of five screens (screen sizes: 2000, 500, 250, 125, $62 \mu \mathrm{m}$ ). The null hypothesis of no difference in OMC and each grain size fraction along intertidal levels was evaluated by one-way ANOVA with a posteriori Tukey test (Zar, 1999).

\section{Tagelus plebeius distribution pattern, size structure and shell morphology}

At each site the density of Tagelus plebeius was estimated by counting siphon holes on the sediment surface, a measure that approximates the number of bivalves reasonably well and is not disruptive to the intertidal environment (see Holland \& Dean, 1977a; Iribarne et al., 1998). Between five to ten randomly placed replicates of $0.25 \mathrm{~m}^{2}$ area were examined at each site and tidal level. The null hypothesis of no difference in the density of T. plebeius between intertidal levels was then tested by Kruskal-Wallis non-parametric analysis (Zar, 1999) with multiple comparisons of mean ranks of all groups, as the assumptions for a parametric test were not fulfilled.

At each site, $30-100$ bivalves $(\mathrm{N}=2491)$ were collected by excavating the sediment using a shovel. Shell length (L; the anterior-posterior axis), height $(\mathrm{H}$; from the umbo to the ventral margin), width ( $W$; all with precision $\pm 0.1 \mathrm{~mm})$, total Mass (TM) and shell mass (SM) were determined (precision $\pm 0.01 \mathrm{~g}$ ). Then, the internal tissues were dried at $70^{\circ} \mathrm{C}$ to constant mass in order to obtain the shell free dry mass (SFDM; precision $\pm 0.001 \mathrm{~g}$ ). The relations between $\mathrm{H}, \mathrm{L}, \mathrm{W}, \mathrm{TM}, \mathrm{SM}$ and SFDM were fitted to the best model (linear or exponential).

\section{Internal shell growth pattern and growth rate of T. plebeius}

Subsamples for growth analysis were obtained from each area and tidal level $(\mathrm{N}=626)$. Individual age was inferred from internal shell growth bands (following Richardson, 2001) of the left valve. Each valve was embedded in polyester resin and sectioned along the axis of maximum growth in height $(H)$ using a Bosch GDC 34 saw with a diamond blade. The cross-sections were polished on lapidary wheels using grits of $400,600,1200,2400$ and 4000 grade, and etched $14 \mathrm{~min}$ using $0.5 \%$ DE-CAL agent. Acetate peel replicates of the crosssectioned surfaces were produced following Rhoads \& Lutz (1980) and examined microscopically. The number of internal translucent bands and the corresponding length were recorded as age-length data (following age validation in next section)

The von Bertalanffy growth model was fitted to the shell length-at-age data using:

$$
L_{\mathrm{t}}=L_{\infty}\left(1-e^{-k\left(t-t_{0}\right)}\right)[\mathrm{mm}, \mathrm{y}]
$$


where $L_{\infty}$ is the asymptotic length, $k$ is the growth constant, $t$ the age and $t_{\mathrm{o}}$ the age at zero length. To fit the model to the data, the maximum likelihood method was used (following Edwards, 1992; Hilborn \& Mangel, 1997).

Additionally, in order to compare the growth across intertidal levels, the von Bertalanffy $k, t_{\mathrm{o}}$ and $L_{\infty}$ parameters from each intertidal level were compared by pair-wise comparisons using the Likelihood ratio test (Cerrato, 1990), and bivariate confidence limits $(\mathrm{Cl})$ for $k, t_{\mathrm{o}}$ and $L_{\infty}$ were built using profile likelihood (see Hilborn \& Mangel, 1997).

\section{Timing of growth band formation}

Under stereomicroscopy, the internal shell growth bands can be identified as translucent and opaque bands (Jones et al., 1990). If major growth bands were formed annually, then one winter growth line (translucent band) should have been formed in the shell part grown during one year. Thus, the annual formation of internal shell growth bands was verified by a one-year tagging-recapture field experiment. Sixty individuals of varying size $(40.5-63.25 \mathrm{~mm} \mathrm{~L})$ were collected from MIL, measured and marked with numbered plastic labels adhered to the surface of the periostracum. The animals were then returned to the intertidal area and allowed to bury each in an individual enclosure consisting of a PVC tube ( $10 \mathrm{~cm}$ diameter and $50 \mathrm{~cm}$ height) open in the top that was vertically buried in the sediments. The wall of these tubes was perforated to allow for the horizontal flow of water through the enclosure. After one year the animals were recovered, the increment in length was determined, the internal shell growth pattern was examined using the acetate peel technique (see above) and the number of translucent and opaque growth bands formed during the experimental time was registered.
Additionally, the annual band formation (see Results section) was confirmed using trace element profiles derived by laser ablation - inductively coupled plasma - mass spectrometry (LA-ICP-MS) at Bremen University (Bremen, Germany). A shell was embedded in polyester resin and sectioned along the axis of maximum growth in height $(\mathrm{H})$ and polished on lapidary wheels as described above. The section was rinsed with deionized water and allowed to dry in a clean hood. Shell material was ablated by a Finnigan $266 \mathrm{~nm}$ laser probe (settings: laser energy $1.0 \mathrm{~mJ}$, pulse rate $5 \mathrm{~Hz}$, beam diameter $40 \mu \mathrm{m})$ using helium as sample gas in the ablation cell $\left(0.41 \mathrm{~min}^{-1}\right)$ and subsequent addition of argon as make-up gas $\left(0.81 \mathrm{~min}^{-1}\right)$. The isotopes ${ }^{43} \mathrm{Ca}$ and ${ }^{88} \mathrm{Sr}$ were measured by a ThermoFinnigan (plasma power $1200 \mathrm{~W}$, low resolution, $160 \mathrm{~ms}$ dwell time per isotope). We used the NIST610 glass standard reference for external calibration (Pearce et al., 1997); external reproducibility for $\mathrm{Sr} / \mathrm{Ca}$ of this standard was $1-2 \%$. Samples were collected $(N=120)$ with an average distance of $65 \mu \mathrm{m}$ along the growth trajectory until an annual band was reached that was too narrow to collect four or more samples. Every five samples the NIST610 standard was measured and a new calibration line established in order to compensate for instrument drift. The calculated $\mathrm{Sr} / \mathrm{Ca}$ ratios were related to the position of the translucent and opaque bands in the shell and a $t$-test was made to test the null hypothesis of no difference in the mean $\mathrm{Sr} / \mathrm{Ca}$ ratios between translucent and opaque bands (Zar, 1999).

\section{RESULTS}

\section{Sediment characteristics}

Sediments of the different sites differed in a wide variety of physical properties.

Table 1. Granulometry of the different sampling sites in Mar Chiquita Coastal Lagoon.

\begin{tabular}{|c|c|c|c|c|c|c|c|c|c|c|}
\hline Site & $\begin{array}{c}\text { Intertidal } \\
\text { level }\end{array}$ & $\begin{array}{c}\text { Mean } \\
\text { grain } \\
\text { size } \\
(\mathrm{mm})\end{array}$ & $\begin{array}{l}\text { Median } \\
\text { grain size } \\
(\mathbf{m m})\end{array}$ & $\begin{array}{c}\text { Very } \\
\text { coarse } \\
\text { sand } \\
\text { (>2 } \mathbf{~ m m})\end{array}$ & $\begin{array}{c}\text { Coarse } \\
\text { sand }(2- \\
0.5 \mathrm{~mm})\end{array}$ & $\begin{array}{c}\text { Medium } \\
\text { sand }(0.5- \\
0.25 \mathrm{~mm})\end{array}$ & $\begin{array}{c}\text { Fine sand } \\
(0.25- \\
0.125 \mathrm{~mm})\end{array}$ & $\begin{array}{c}\text { Very fine } \\
\text { sand (0.125- } \\
0.062 \mathrm{~mm})\end{array}$ & $\begin{array}{c}\text { Silt-clay } \\
(<0.062 \mathrm{~mm})\end{array}$ & $\begin{array}{c}\text { Mean } \\
\text { Organic } \\
\text { matter (\%) }\end{array}$ \\
\hline \multirow[t]{3}{*}{ A } & Low & 0.20 & 0.0935 & $4.8(0.8)$ & $1(0.3)$ & $1(0.3)$ & $26.7(2.8)$ & $32.1(2.4)$ & $35(3.6)$ & 3.52 \\
\hline & Medium & 0.13 & 0.0935 & $1.4(0.9)$ & $0.6(0.2)$ & $0.6(0.2)$ & $24.6(2.8)$ & $33.8(5.7)$ & $39.1(6.5)$ & 3.49 \\
\hline & High & 0.12 & 0.0935 & $1(0.5)$ & $0.7(0.1)$ & $0.7(0.1)$ & $21.8(2.1)$ & $40.4(1.5)$ & $35 \cdot 3(1.6)$ & 3.29 \\
\hline \multirow[t]{3}{*}{ B } & Low & 0.27 & 0.0935 & $7.7(1.9)$ & $2.7(0.7)$ & $2.7(0.7)$ & $17.5(2.6)$ & $25.8(2)$ & $45 \cdot 3(4.6)$ & 3.69 \\
\hline & Medium & 0.19 & 0.0935 & $3.8(0.3)$ & $2.1(0.3)$ & $2.1(0.3)$ & $21.8(1.7)$ & $29.2(2)$ & $42.4(3.4)$ & 3.18 \\
\hline & High & 0.19 & 0.0935 & $3.7(1.2)$ & $2.2(0.3)$ & $2.2(0.3)$ & $23.4(4.7)$ & $31.1(3.3)$ & $38.8(5.4)$ & 3.24 \\
\hline \multirow[t]{3}{*}{$\mathrm{C}$} & Low & 0.40 & 0.1875 & $2.9(1.2)$ & $17.1(2.8)$ & $17.1(2.8)$ & $25.3(4.2)$ & $9.3(1)$ & $30.9(4.5)$ & 3.23 \\
\hline & Medium & 0.43 & 0.1875 & $2.1(1.2)$ & $19.3(3.5)$ & $19.5(3.3)$ & $31.8(6.5)$ & $7(1.8)$ & $18(4.8)$ & 2.01 \\
\hline & High & 0.48 & 0.1875 & $2.6(1.5)$ & $23.1(11.4)$ & $19(4.7)$ & $32.3(7.5)$ & $8.5(1.5)$ & $10.1(4.2)$ & 1.51 \\
\hline \multirow[t]{3}{*}{$\mathrm{D}$} & Low & 0.10 & 0.031 & $0.6(0.5)$ & $1.7(0.6)$ & $1.7(0.6)$ & $13 \cdot 3(4)$ & $17.6(5.3)$ & $64.6(10)$ & 5.38 \\
\hline & Medium & 0.12 & 0.031 & $0.6(0.1)$ & $2.1(0.8)$ & $2.1(0.8)$ & $17(1.5)$ & $23.2(2.5)$ & $54.9(2.7)$ & 3.58 \\
\hline & High & 0.20 & 0.0935 & $1.6(0.2)$ & $6(1.7)$ & $6(1.7)$ & $21.9(1.1)$ & $16.6(0.9)$ & $48(2.6)$ & 3.43 \\
\hline \multirow[t]{3}{*}{$\mathrm{E}$} & Low & 0.36 & 0.0935 & $7.7(2.3)$ & $7.2(1.8)$ & $7.2(1.8)$ & $30(4.7)$ & $20.3(2.5)$ & $32.1(8.4)$ & 3.04 \\
\hline & Medium & 0.44 & 0.1875 & $11.9(3.6)$ & $7.5(1.2)$ & $7.5(1.2)$ & $27.7(3.3)$ & $23.1(1.7)$ & $26.8(2.8)$ & 3.01 \\
\hline & High & 0.36 & 0.0935 & $9.1(2.5)$ & $6.4(2.1)$ & $6.4(2.1)$ & $23.1(3.9)$ & $16.8(3.4)$ & $42.5(6)$ & 3.04 \\
\hline \multirow[t]{3}{*}{$\mathrm{F}$} & Low & 0.095 & 0.031 & $0.8(0.6)$ & $0.6(0.3)$ & $0.6(0.3)$ & $17(2.6)$ & $21.4(3.3)$ & $59.7(6)$ & 4.66 \\
\hline & Medium & 0.15 & 0.0935 & $1.9(1.3)$ & $1.5(0.5)$ & $1.5(0.5)$ & $25.2(3.5)$ & $26.1(3.5)$ & $44 \cdot 3(5)$ & 3.10 \\
\hline & High & 0.15 & 0.0935 & $2(0.4)$ & $1.8(0.1)$ & $1.8(0.1)$ & $21.4(1.8)$ & $29(2.6)$ & $44.9(4.5)$ & 3.17 \\
\hline \multirow[t]{3}{*}{ G } & Low & 0.24 & 0.0935 & $6.4(1.5)$ & $2.6(0.9)$ & $2.6(0.9)$ & $17.6(1.6)$ & $23.9(1.5)$ & $48.4(3.7)$ & 4.03 \\
\hline & Medium & 0.14 & 0.0935 & $1.2(0.8)$ & $1.2(0.4)$ & $1.2(0.4)$ & $30.6(1.6)$ & $29.8(4.8)$ & $36.5(4.8)$ & 3.57 \\
\hline & High & 0.24 & 0.0935 & $3.3(1.8)$ & $5.2(6.8)$ & $5.2(6.8)$ & $29.2(3.8)$ & $26.6(5)$ & $34.7(5.4)$ & 3.58 \\
\hline
\end{tabular}

Values for sediment fractions are expressed in percentage. 




Fig. 2. Morphological relationships in Tagelus plebeius.

Median grain size diameter varied from 0.031 to $>0.1875 \mathrm{~mm}$, mean silt-clay content from 10.1 to $64.6 \%$ and the OMC from $1.51 \%$ in sandy sediments to $5.38 \%$ in the muddiest sediments (Table 1). Sediment organic matter content (OMC) was higher at LIL compared with MIL and HIL (3.94\%, SD $=0.99$ compared with $3.13 \%, S D=0.82$ and $3.04 \%, \mathrm{SD}=0.73$ respectively, $P<0.05)$. The silt and clay sediment fraction $<62 \mu \mathrm{m}$ showed the same pattern as OMC $(P<0.05)$.

\section{Tagelus plebeius distribution pattern, size structure and shell morphology}

The density of T. plebeius was higher at LIL with 61.18 individuals $\mathrm{m}^{-2}(95 \% \mathrm{CI}=54.34$; 68.05) compared with MIL (mean $=23.54$ ind $\left.\mathrm{m}^{-2}, \quad \mathrm{CI}=15.76 ; 31.32\right)$ and HIL $\left(\right.$ mean $=27.14$ ind $\mathrm{m}^{-2} ; \mathrm{CI}=12.15 ; 42.14 ; H_{(2 ; 133)}=60.35$, $P<0.05)$. Shell length ranged from 6.71 to $77.93 \mathrm{~mm}$ with a mean of $52.19 \mathrm{~mm}$; $\mathrm{SD}=14.40$. The morphological relationships are shown in Figure 2.

\section{Tagelus plebeius individual growth}

The internal shell cuts under stereoscopy and acetate peels technique under microscopy showed a pattern of alternating broad opaque and narrow translucent bands (Figure 3). The umbo is not well defined in this species thus, the internal growth bands showed a parallel pattern in this area (Figure ${ }_{3} \mathrm{~B}$ ). It was possible to follow each translucent internal growth band from the umbo throughout the shell section (Figure ${ }_{3} \mathrm{C}, \mathrm{D}$ ) to the point where it crosses the outer shell layer to form an external ring on the shell surface (Figure ${ }_{3} \mathrm{E}, \mathrm{F}$ ). In the ventral (most recent) part of the valve, the internal growth bands were situated closer to the shell edge and more narrowly spaced (individuals $>40 \mathrm{~mm} \mathrm{~L}$ ). These bands were clearly visible in acetate peels but very difficult to identify on the exterior shell surface. 


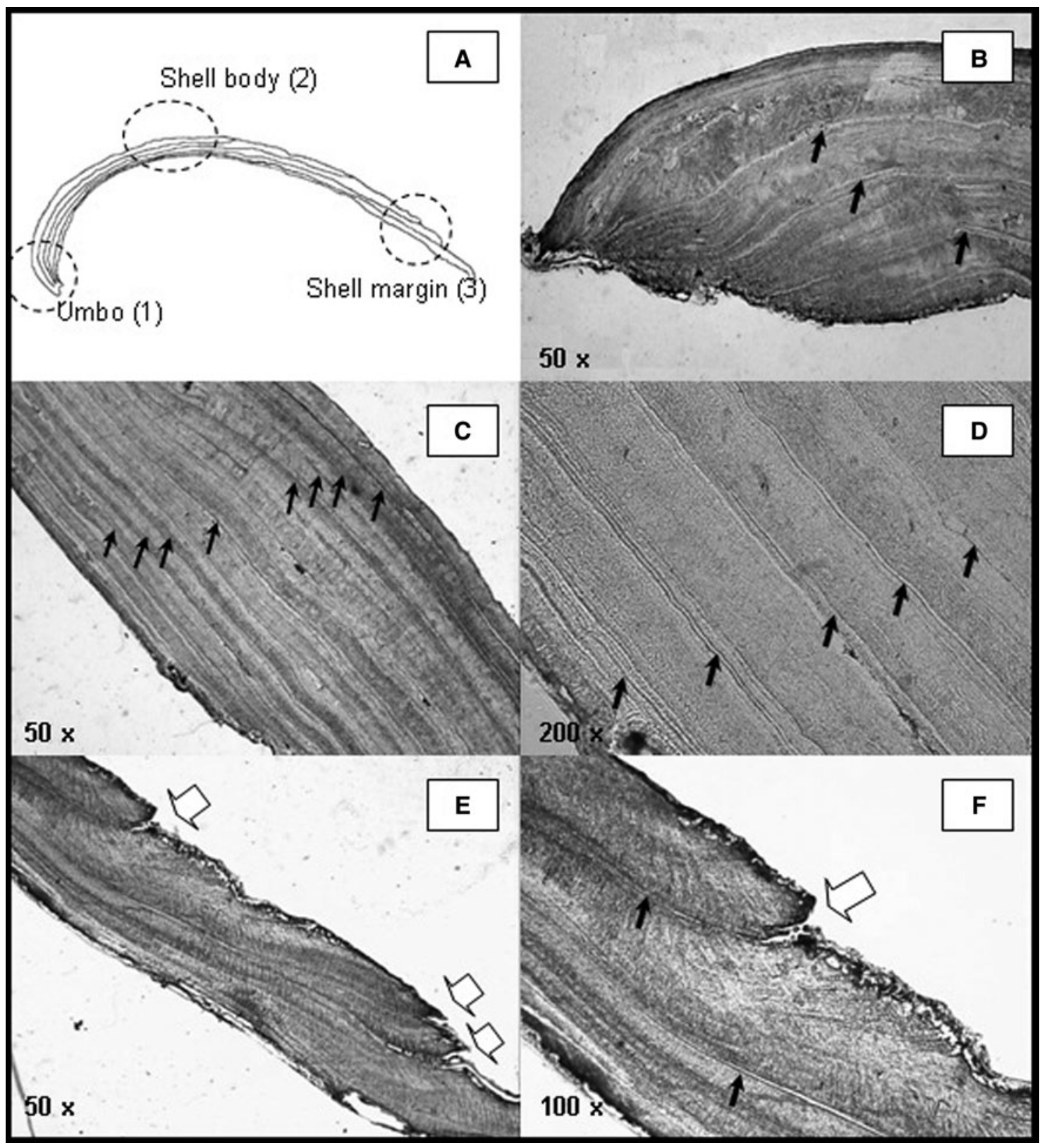

Fig. 3. (A) Scheme of the shell cross section of T. plebeius and acetate peels from (B) umbo, (C, D) body shell, (E, F) shell margin showing the internal growth bands all the way along a cross shell section (black arrows: translucent growth bands) and the point where translucent growth bands cross the outer shell layer to form an exterior ring on the shell surface (white arrows: exterior rings).

A von Bertalanffy model with $L_{\infty}=67.60 \mathrm{~mm}(95 \% \mathrm{CI}=$ $64.55 ; 70.64), \quad k=0.181$ year $^{-1}(\mathrm{CI}=0.142 ; 0.218)$ and $t_{\mathrm{o}}=-0.77(\mathrm{CI}=-1.46 ;-0.08 ; N=626)$ described individual growth in the whole population best (Figure 4). The oldest animal found was 27 years old.

The comparison of the von Bertalanffy parameters from the three intertidal levels (Table 2), showed lower $L_{\infty}$ at LIL than at MIL and HIL, lower $\mathrm{k}$ at MIL than at LIL and HIL, and higher $t_{\mathrm{o}}$ at LIL than at MIL (Likelihood ratio test, $P<$ 0.05; Table 3). The maximum age was higher at LIL (27 years old) than at MIL and HIL (23 years old).

\section{Timing of growth band formation}

From the 60 individuals introduced in the tagging-recapture experiment only 31 survived after one year not showing individual migration across intertidal levels. Analysis of all surviving individual confirmed that one translucent growth band and one opaque growth band were formed each year. The $\mathrm{Sr} / \mathrm{Ca}$ ratio ranged from 1.55 to $3.69 \mathrm{mmol} \mathrm{mol}^{-1}$ along the measurement transect, with higher values located at the translucent growth bands $\left(\right.$ mean $=2.66 ; \mathrm{SD}=0.34 \mathrm{mmol} \mathrm{mol}^{-1}$ ) compared with the samples from the opaque bands (mean $=$ 2.31; $\left.\mathrm{SD}=0.36 \mathrm{mmol} \mathrm{mol}^{-1}\right) \quad\left(t\right.$-test $_{118}=2.92 ; \quad P<0.05$; Figure 5).

\section{DISCUSSIDN}

The population of Tagelus plebeius from Mar Chiquita coastal lagoon consisted of individuals of up to 27 years old, with shells up to $77.93 \mathrm{~mm}$ length. Comparison of density and 


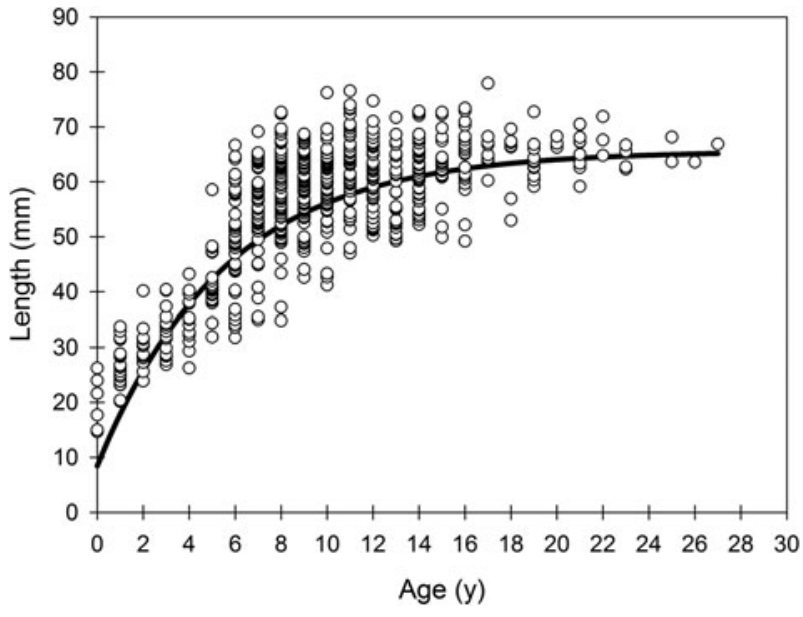

Fig. 4. Size-at-age data and corresponding von Bertalanffy growth curve in Tagelus plebeius from Mar Chiquita coastal lagoon.

growth parameters and maximum age between intertidal levels showed higher density, growth rate $k, t_{0}$ and maximum age and lower $L_{\infty}$ at LIL than at MIL, associated with no difference in density and age between MIL and HIL.

Higher density of T. plebeius are commonly associated with muddy sediments of high organic content (e.g. Holland \& Dean, 1977a; Abrahão \& Amaral, 1999; Lomovasky et al., 2006; this study), while populations associated with sandy and muddy-sandy sediments show lower densities (Abrahão et al., 2010; de Farias \& Rocha-Barreira, 2012). The sediment characteristics could be an indicator of environmental stability and food availability for suspension feeding species, which are facilitated by fine sediments and high OMC (da Silva et al., 2015). Similarly, a higher growth index was associated to finer sand but higher OMC in different localities from Brazil (da Silva et al., 2015). The sediment at all sites sampled in the present study was composed of $>10 \%$ silt-clay, reaching $64 \%$ in some areas. Thus, the whole tidal flat is composed of sandy-muddy and muddy sediments such as described at North Inlet estuary, South Carolina $\left(33^{\circ} 20^{\prime} \mathrm{N} 79^{\circ} 10.0^{\prime} \mathrm{W}\right.$, USA) where these more stable sediments facilitate $T$. plebeius (Holland \& Dean, 1977a).

This study showed that T. plebeius has a pattern of alternating broad opaque and narrow translucent growth bands observed in internal shell cuts under stereoscopy and acetate peels under microscopy, which represent alternating periods of fast and slow shell growth respectively. Elevated $\mathrm{Sr} / \mathrm{Ca}$ ratios along a shell coincide with translucent bands formed during winter as confirmed by our annual field experiment. This inverse relationship between $\mathrm{Sr} / \mathrm{Ca}$ ratios and water temperature may render $\mathrm{Sr} / \mathrm{Ca}$ a suitable indicator of the seasonal formation of growth bands in T. plebeius, as found in some further species with aragonite shells (Dodd, 1965; Surge \&
Table 3. Results of Likelihood ratio test for pair-wise comparison for $k$, $L_{\infty}$ and $t_{\mathrm{o}}$ parameters between different intertidal levels.

\begin{tabular}{llll}
\hline & & \multicolumn{2}{c}{ Likelihood ratio test } \\
\cline { 3 - 4 } Intertidal levels & \multicolumn{1}{c}{$\boldsymbol{H}_{\mathbf{o}}$} & $\boldsymbol{\chi}_{(\mathbf{d f =})}^{2}$ & $\boldsymbol{P}$-value \\
\hline Low-medium & $L_{\infty 1}=L_{\infty 2}$ & 9.93 & $0.0016^{*}$ \\
& $k_{1}=k_{2}$ & 7.94 & $0.0048^{*}$ \\
& $t_{\mathrm{o} 1}=t_{\mathrm{o} 2}$ & 4.49 & $0.0340^{*}$ \\
Low-high & $L_{\infty 1}=L_{\infty 2}$ & 4.07 & $0.0430^{*}$ \\
& $k_{1}=k_{2}$ & 1.39 & 0.2372 \\
\multirow{2}{*}{ Medium-high } & $t_{\mathrm{o} 1}=t_{\mathrm{O} 2}$ & 0.69 & 0.4040 \\
& $L_{\infty 1}=L_{\infty_{2}}$ & 3.38 & 0.066 \\
& $k_{1}=k_{2}$ & 4.22 & $0.040^{*}$ \\
& $t_{\mathrm{o} 1}=t_{\mathrm{o} 2}$ & 3.31 & 0.069 \\
\hline
\end{tabular}

Asterisks indicate a significance of $P<0.05$

Walker, 2006), but not in all species analysed so far (see Palacios et al., 1994; Freitas et al., 2005; Gillikin et al., 2005; Schöne et al., 2011).

The maximum lifespan of 27 years in the recent Mar Chiquita population is much higher than values reported for fossil shells from the same location (8 years, Isla \& D'Andrea, 1993) and from different sites in Brazil, below 3 years at Enseada Beach $\left(23^{\circ} 43^{\prime} \mathrm{S} 45^{\circ} 25^{\prime} \mathrm{W}\right)$ in São Sebastião (Abrahão et al., 2010), and at Camaroeiro Beach $\left(23^{\circ} \mathrm{S}\right.$ $45^{\circ} \mathrm{W}$ ) in Caraguatatuba Bay (da Silva et al., 2015). However, those studies evaluated growth rate and maximum age using shell size frequency analyses (Abrahão et al., 2010; da Silva et al., 2015) and external growth rings (Isla \& D'Andrea, 1993). Both methods are highly prone to underestimate age in long-lived species where annual growth increments may become quite small. In such cases, analysis of internal shell growth bands is the appropriate approach (Rhoads \& Lutz, 1980; Richardson, 2001). Hence, only a proper re-analysis of the shells used in the previous studies will show whether we are dealing with an increase of maximum lifespan with decreasing ambient temperature, as observed in other bivalve species (e.g. Lomovasky et al., 2008,2011 ), or with a distinct underestimation of individual age in the previous studies. Although the difference between our analysis and those previously reported may lead to the hypothesis of changes in growth rate, we believe that it is most likely due to deficiencies of the used techniques.

Processes governing benthic populations along an intertidal gradient in soft sediment substrates had been studied in different systems (e.g. Peterson \& Beal, 1989; Nakaoka, 2000; Beal, 2006), in general determining a distribution pattern for bivalve species of higher density and higher shell growth rate in the low intertidal compared with the medium and high intertidal levels (Holland \& Dean, 1977b; Marsden \& Weatherhead, 1999; Gosling, 2003) related to physiological stress and/or biological interactions. In this sense, T. plebeius

Table 2. Parameters of the general von Bertalanffy growth function with confidence limits (CI) at alpha 0.05 in Tagelus plebeius from the low, medium and high intertidal levels.

\begin{tabular}{lccccc}
\hline Intertidal level & $\boldsymbol{L}_{\infty}(\mathbf{m m})(\mathbf{C I})$ & $\mathbf{k}\left(\mathbf{y}^{-\mathbf{1}}\right)(\mathbf{C I})$ & $\boldsymbol{t}_{\mathrm{o}}(\mathbf{y})(\mathbf{C I})$ & $\boldsymbol{n}$ & $\boldsymbol{L}_{\text {max }}(\mathbf{m m})$ \\
\hline Low & $64.96(62.96 ; 66.97)$ & $0.214(0.167 ; 0.262)$ & $-0.20(-1.04 ; 0.64)$ & 229 & 76.23 \\
Medium & $73.96(65.40 ; 82.51)$ & $0.131(0.081,0.180)$ & $-1.51(-2.63 ;-0.39)$ & 159 & 77.93 \\
High & $68.1(65.11 ; 71.09)$ & $0.184(0.147,0.221)$ & $-0.585(-1.204 ; 0.035)$ & 238 & 72.67 \\
\hline
\end{tabular}




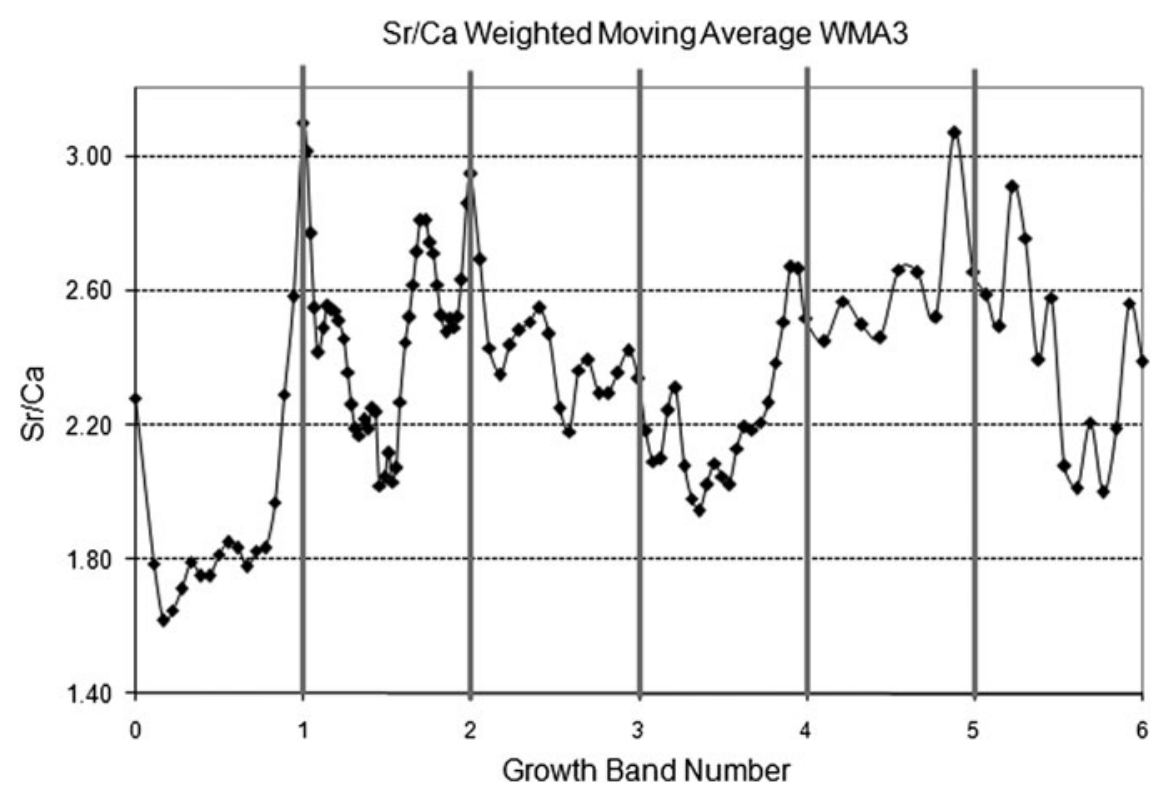

Fig. 5. Analysed $\mathrm{Sr} / \mathrm{Ca}$ ratios from an individual of Tagelus plebeius 6 years old related to the position of translucent growth bands.

showed higher density at LIL than at MIL and HIL and this was correlated with higher percentage of OMC and muddy sediments at LIL (Lomovasky et al., 2006 and this study). Similar results were found in the North Inlet estuary located near Georgetown, South Carolina $\left(33^{\prime \prime} 20^{\prime} \mathrm{N} 79^{\prime \prime} 10^{\prime} \mathrm{W}\right)$ with higher density of $T$. plebeius in low intertidal $\left(<200\right.$ ind $\left.\mathrm{m}^{-2}\right)$ and low density in the high intertidal $\left(<5\right.$ ind $\left.\mathrm{m}^{-2}\right)$ (Holland \& Dean, 1977a), and in other filter feeder bivalves inhabiting intertidal areas (e.g. Crosby et al., 1991; Kingsley-Smith et al., 2009; Lomovasky et al., 2014). Shell growth displayed a similar pattern across the intertidal, with faster growth at LIL compared with MIL, but no differences was observed between LIL and HIL. Distribution and growth patterns of bivalve species across tidal flats have been related to the level of physiological stress and to feeding restrictions that increase from low to high tidal levels (Dame, 1972; Marsden \& Weatherhead, 1999; Gosling, 2003). In T. plebeius which did not show migration across the intertidal (Holland \& Dean, 1977b; this study), this hypothesis could explain the density patterns found (higher at LIL than at HIL) in part by differential adult mortality and/or survival of recruits. However, shell growth rate is higher both at HIL and LIL compared with MIL, which leads to the belief that other, yet unknown factors are likely to play a role here.

Biological interactions such as predation (e.g. Bartol et al., 1999; Bologna \& Heck, 1999; Nakaoka, 2000), competition (e.g. Peterson \& Beal, 1989; Cognie et al., 2006) and/or parasitism (e.g. Lim \& Green, 1991; Taskinen, 1998) can also affect bivalve distribution and size. Different biological interactions affect T. plebeius shell growth (e.g. with crabs, parasites, predators: Lomovasky et al., 2005, 2006; with salt marsh plants: Addino et al., 2015). In this sense, in the Mar Chiquita coastal lagoon the co-habiting of bivalves with the crab Neohelice granulata showed that this crab negatively affects the morphology and growth of $T$. plebeius differentially across the intertidal (Lomovasky et al., 2006). Negative effects become stronger toward the low intertidal, where the burrowing and migrating of crabs may disrupt bivalve feeding and/or may force bivalves to invest more energy into escape movements and burrow rebuilding, thus leaving less energy for growth (Lomovasky et al., 2006). In areas without crabs, there is a strong effect of intertidal level on morphology and growth showing the typical gradient of intertidal distribution, density and growth (see Lomovasky et al., 2006). Thus, the crabs add an additional effect (although with the opposite gradient to the physiological stress); as we did not discriminate areas with and without crabs looking at the system as a whole this particular process was masked in our results. Additionally, a strong predation pressure by the American oystercatcher Haematopus palliates (Bachmann \& Martínez, 1999) was observed in the study site. In this case a strong interaction with parasitism by the gymnophallid metacercariae, which increases the bivalves available for predators, was observed in the medium intertidal zone (see Lomovasky et al., 2005; Addino et al., 2010). Thus, the intertidal differences in growth rate are likely to be mediated by the presence of the crabs, parasitism and strong predation causing the slower growth rate at MIL found in this study. In conclusion, we hypothesize that the distribution pattern and razor clam characteristics reflect a response to the combined effects of the physical tidal stress gradient and strong biological interactions.

\section{ACKNDWLEDGEMENTS}

We thank Agustina Mendez Casariego, Cecilia Ravelli, Martin Bruschetti and Jorge Gutierrez (from UNMDP, Argentina) for field assistance and, Kerstin Beyer (from AWI, Germany) for technical assistance.

\section{FINANCIAL SUPPDRT}

This project was supported by grants from Universidad Nacional de Mar del Plata (15/E214), FONCyT (PICT-2012-0402), CONICET (Argentina; PIP No. 424), and by the 
German-Argentinean Bilateral Cooperation Program in Science and Technology (BMBF: ARGo2-002 and MinCyT: AL/ $\mathrm{PA02}-\mathrm{BI} / 002$ and $\mathrm{AL} / 09 / 06)$.

\section{REFERENCES}

Abrahão J.R. and Amaral A.C.Z. (1999) Tamanho, densidade e distribuição de Tagelus plebeius (Venereide, Psammobiidae) em uma praia arenosa, São Paulo, Brasil. Iheringia, Série Zoologia 87, 181-190.

Abrahão J.R., Cardoso R.S., Yokoyama L.Q. and Amaral A.C.Z. (2010) Population biology and secondary production of the stout razor clam Tagelus plebeius (Bivalvia, Solecurtidae) on a sandflat in southeastern Brazil. Zoologia (Curitiba) 27, 54-64.

Addino M., Alvarez M.F., Iribarne O. and Lomovasky B.J. (2016) Interaction between a mobile and a sessile species in SW Atlantic mudflats: there are no negative effects of the crab Cyrtograpsus angulatus Dana, 1851 on filtration rate and growth of the infaunal clam Tagelus plebeius (Lightfoot, 1786). Journal of Experimental Marine Biology and Ecology 476, 65-71.

Addino M., Lomovasky B.J., Cremonte F. and Iribarne O. (2010) Infection by gymnophallid metacercariae enhance predation mortality of SW Atlantic stout razor clam Tagelus plebeius. Journal of Sea Research 63, 102-107.

Addino M., Montemayor D., Escapa M., Alvarez F., Valiñas M. Lomovasky B.J. and Iribarne O. (2015) Effect of Spartina alterniflora on growth of the stout razor clam Tagelus plebeius in a SW Atlantic estuary. Journal of Experimental Marine Biology and Ecology 463 $135-142$.

Aguirre M.L. and Farinati E.A. (1999) Taphonomic processes affecting late Quaternary molluscs along the coastal area of Buenos Aires Province (Argentina; Southwestern Atlantic). Palaeogeography, Palaeoclimatology and Palaeoecology 149, 283-304.

Arneri E., Giannetti G. and Antolini B. (1998) Age determination and growth of Venus verrucosa L. (Bivalvia: Veneridae) in the southern Adriatic and the Aegean Sea. Fisheries Research 38, 193-198.

Arruda E.P., Domaneschi O. and Amaral A.C.Z. (2003) Mollusc feeding guilds on sandy beaches in Sao Paulo State, Brazil. Marine Biology 143 $691-701$.

Bachmann S. and Martínez M.M. (1999) Feeding tactics of the American Oystercatcher (Haematopus palliatus) on Mar Chiquita coastal lagoon, Argentina. Ornitología Neotropical 10, 81-84.

Bartol I.K., Mann R. and Luckenbach M. (1999) Growth and mortality of oysters (Crassostrea virginica) on constructed intertidal reefs: effects of tidal height and substrate level. Journal of Experimental Marine Biology and Ecology 237, 157-184.

Beal B.F. (2006) Relative importance of predation and intraspecific competition in regulating growth and survival of juveniles of the soft-shel clam, Mya arenaria L., at several spatial scales. Journal of Experimental Marine Biology and Ecology 336, 1-17.

Beukema J.J. and Cadée G.C. (1991) Growth rate of the bivalve Macoma balthica in the Wadden Sea during a period of eutrophication: relationships with concentrations of pelagic diatoms and flagellates. Marine Ecology Progress Series 68, 249-256.

Beukema J.J. and Desprez M. (1986) Single and dual annual growing seasons in the tellind bivalve Macoma balthica (L.). Journal of Experimental Marine Biology and Ecology 102, 35-45.

Bologna P.A.X. and Heck K.L. Jr (1999) Differential predation and growth rates of bay scallops within a seagrass habitat. Journal of Experimental Marine Biology and Ecology 239, 299-314.
Cerrato R.M. (1990) Interpretable statistical test for growth comparisons using parameters in the von Bertalanffy equation. Canadian Journal of Fisheries and Aquatic Sciences 47, 1416-1426.

Ceuta L.O. and Boehs G. (2012) Reproductive cycle of Tagelus plebeius (Mollusca: Bivalvia) in the estuary of the Cachoeira River, Ilhéus, Bahia, Brazil. Brazilian Journal of Biology 72, 569-576.

Cledón M., Peralta Brichtova A.C., Gutiérrez J.C. and Penchaszadeh P.E. (2004) Reproductive cycle of the stout razor clam, Tagelus plebeius (Lightfoot, 1786), in the Mar Chiquita coastal lagoon, Argentina. Journal of Shellfish Research 23, 443-446.

Cognie B., Haure J. and Barillé L. (2006) Spatial distribution in a temperate coastal ecosystem of the wild stock of the farmed oyster Crassostrea gigas (Thunberg). Aquaculture 259, 249-259.

Crosby M.P., Roberts C.F. and Kenny P.D. (1991) Effects of immersion time and tidal position on in situ growth rates of naturally settled eastern oysters, Crassostrea virginica (Gmelin, 1791). Journal of Shellfish Research 10, 95-103.

Dame R.F. (1972) The ecological energies of growth, respiration, and assimilation in the intertidal American oyster Crassostrea virginica. Marine Biology 17, 243-250.

da Silva C.F., Corte G.N., Yokoyama L.Q., Rodrigues Abrahão J. and Zacagnini Amaral A.C. (2015) Growth, mortality, and reproduction of Tagelus plebeius (Bivalvia: Solecurtidae) in Southeast Brazil. Helgoland Marine Research 69, 1-12.

de Farias M.F. and Rocha-Barreira C.D.A. (2012) Population aspects of Tagelus plebeius (Mollusca: Bivalvia: Solecurtidae) in the Ceara river estuary, Ceara state, northeast Brazil. Arquivos de Ciências do Mar (Brazil) 45, 32-39.

Dekker R. and Beukema J.J. (1999) Relations of summer and winter temperatures with dynamics and growth of two bivalves, Tellina tenuis and Abra tenuis, on the northern edge of their intertidal distribution. Journal of Sea Research 42, 207-220.

Dodd J.R. (1965) Environmental control of strontium and magnesium in Mytilus. Geochimica et Cosmochimica Acta 29, 385-398.

Edwards A.W.F. (1992) Likelihood, expanded edition. Baltimore, MD: Johns Hopkins University Press.

Fasano J.L., Hernández M.A., Isla F.I. and Schnack J.E. (1982) Aspectos evolutivos y ambientales de la Laguna Mar Chiquita (provincia de Buenos Aires, Argentina). Oceanologica Acta 4, 285-292.

Freitas P., Clarke L.J., Kennedy H., Richardson C. and Abrantes F. $(2005) \mathrm{Mg} / \mathrm{Ca}, \mathrm{Sr} / \mathrm{Ca}$, and stable-isotope $(\delta 18 \mathrm{O}$ and $\delta 13 \mathrm{C})$ ratio profiles from the fan mussel Pinna nobilis: seasonal records and temperature relationships. Geochemistry, Geophysics, Geosystems 6, Q04D14. doi: 10.1029/2004GCooo872.

Gillikin D.P., Lorrain A., Navez J., Taylor J.W., André L., Keppens E. and Dehairs F. (2005) Strong biological controls on $\mathrm{Sr} / \mathrm{Ca}$ ratios in aragonitic marine bivalve shells. Geochemistry, Geophysics, Geosystems 6, Q05009. doi: 10.1029/2004GCo00874.

Golfieri G.A., Ferrero L. and Zárate M. (1998) Tafonomía y paleoecología de Tagelus plebeius (Lightfoot, 1786) (Mollusca, Bivalvia) en sedimentos Holocenos del Río Quequén Grande, Provincia de Buenos Aires, Argentina. Ameghiniana 35, 255-264.

Gosling E. (2003) Bivalve molluscs: biology, ecology, and culture. Malden, MA: Blackwell Publishing.

Green R.H. (1973) Growth and mortality in an Arctic intertidal population of Macoma balthica (Pelecypoda, Tellinidae). Journal of the Fisheries Board of Canada 30, 1345-1348.

Gutiérrez N. and Defeo O. (2003) Development of new scallop Zygochlamys patagonica fishery in Uruguay: latitudinal and 
bathymetric patterns in biomass and population structure. Fisheries Research 62, 21-36.

Hilborn R. and Mangel M. (1997) The ecological detective: confronting models with data. (Monographs in Population Biology no. 28). Princeton, NJ: Princeton University Press.

Holland A.F. and Dean J. (1977a) The biology of the stout razor clam Tagelus plebeius. 1. Animal-sediment relationships, feeding mechanism and community biology. Chesapeake Science 18, 58-66.

Holland A.F. and Dean J. (1977b) The biology of the stout razor clam Tagelus plebeius. 2. Some aspects of the population dynamics. Chesapeake Science 18, 188-196.

Iribarne O. and Botto F. (1998) Orientation of the extant stout razor clam Tagelus plebeius in relation to current direction: its paleoecologic implications. Journal of Shellish Research 17, 165-168.

Iribarne O., Valero J., Martínez M.M., Lucifora L. and Bachmann S. (1998) Shorebird predation may explain the origin of Holocene beds of stout razor clams in life position. Marine Ecology Progress Series $167,301-306$.

Isla F.I. and D'Andrea I.R. (1993) Procesos retrotafonómicos en secuencias de aguas someras. Pesquisas 20, 90-95.

Jones D.S., Arthur M.A. and Allard D.J. (1989) Sclerochronological records of temperature and growth from shells of Mercenaria mercenaria, Narragansett Bay, Rhode Island. Marine Biology 102, 225-234.

Jones D.S., Quitmyer I.R., Arnold W.S. and Marelli D.C. (1990) Annual shell banding, age, and growth rate of hard clams (Mercenaria spp.) from Florida. Journal of Shellfish Research 9, 215-225.

Kingsley-Smith P.R., Harwell H.D., Kellogg M.L., Allen S.M., Allen S.C. Jr, Meritt D.W., Paynter K.T. Jr and Luckenbach M.W. (2009) Survival and growth of triploid Crassostrea virginica (Gmelin, 1791) and C. ariakensis (Fujita, 1913) in bottom environments of Chesapeake Bay: implications for an introduction. Journal of Shellfish Research 28, 169-184.

Kube J., Peters C. and Powilleit M. (1996) Spatial variation in growth of Macoma balthica and Mya arenaria (Mollusca, Bivalvia) in relation to environmental gradients in the Pomeranian Bay (Southern Baltic Sea). Archive of Fishery and Marine Research 44, 81-93.

Lai H.L., Gallucci V.F., Gunderson D.R. and Donnelly R.F. (1996) Age determination in fisheries: methods and applications to stock assessment. In Gallucci V.F., Saila S.B., Gustafson D.J. and Rothschild B.J. (eds) Stock assessment: quantitative methods and applications for small-scale fisheries, pp. $82-178$.

Leal J.H. (2002) Bivalvia. In Carpenter K.E. (ed.) The living marine resources of the western Central Atlantic. I: Introduction, mollusks, crustaceans, hagfishes, sharks, batoid fishes and chimaeras. FAO Identification guide for fishery purposes. Rome: FAO, pp. 25-98.

Lim S.S. and Green R.H. (1991) The relationship between parasite load crawling behaviour, and growth rate of Macoma balthica (L.) (Mollusca, Pelecypoda) from Hudson Bay, Canada. Canadian Journal of Zoology 69, 2202-2208.

Lomovasky B.J., Alvarez G., Addino M., Montemayor D. and Iribarne $O$. (2014) A new non- indigenous Crassostrea species in Southwest Atlantic salt marshes affects mortality of the cordgrass Spartina alterniflora. Journal of Sea Research 90, 16-22.

Lomovasky B.J., Baldoni A., Ribeiro P., Alvarez G.I., Lasta M., Campodónico S. and Iribarne O. (2011) Exploring the causes of differences in growth rate of Zygochlamys patagonica along its commercial bed distribution in the SW Atlantic. Journal of Sea Research 66, $162-171$.

Lomovasky B.J., Gutiérrez J. and Iribarne O. (2005) Identifying repaired shell damages and abnormal calcifications in the stout razor clam
Tagelus plebeius as a tool to investigate its ecological interactions. Journal of Sea Research 54, 163-175.

Lomovasky B.J., Lasta M., Valiñas M., Bruschetti M., Ribeiro P., Campodónico S. and Iribarne O. (2008) Differences in shell morphology and internal growth pattern of the Patagonian scallop Zygochlamys patagonica in the four main beds across their SW Atlantic distribution range. Fisheries Research 89, 266-275.

Lomovasky B.J., Mendez Casariego A., Brey T. and Iribarne O. (2006) The effect of the SW Atlantic burrowing crab Chasmagnathus granulatus on the intertidal razor clam Tagelus plebeius. Journal of Experimental Marine Biology and Ecology 337, 19-29.

Marsden I.D. and Weatherhead M.A. (1999) Shore-level induced variations in condition and feeding of the mussel Perna canaliculus from the east coast of the South Island, New Zealand. New Zealand Journal of Marine and Freshwater Research 33, 611-622.

Morton B. (1978) The population dynamics of Anomalocardia squamosa Lamarck (Bivalvia: Veneracea) in Hong Kong. Journal of Molluscan Studies 44, 135-144.

Nakaoka M. (2000) Nonlethal effects of predators on prey populations: predator-mediated change in bivalve growth. Ecology 81, $1031-1045$.

Olivier S.R., Escofet A., Penchaszadeh P. and Orensanz J.M. (1972a) Estudios ecológicos de la region estuarial de Mar Chiquita (Buenos Aires, Argentina). I: Las comunidades bentónicas. Anales de la Sociedad Científica Argentina 193, 237-262.

Olivier S.R., Escofet A., Penchaszadeh P. and Orensanz J.M. (1972b) Estudios ecológicos de la region estuarial de Mar Chiquita (Buenos Aires, Argentina). II: Relaciones tróficas. Anales de la Sociedad Científica Argentina 194, 84-104.

Orensanz J.M. and Jamieson G.S. (1998) The assessment and management of spatially structured stocks: an overview of the North Pacific Symposium on Invertebrate Stock Assessment and Management. Canadian Special Publication of Fisheries and Aquatic Sciences 441-459.

Palacios R., Orensanz J.M. and Armstrong D.A. (1994) Seasonal and lifelong variation of $\mathrm{Sr} / \mathrm{Ca}$ ratio in shells of Mya arenaria from Grays Harbor (Washington) - an ancillary criterion in demographic studies. Estuarine, Coastal and Shelf Science 39, 313-327.

Pearce N.J., Perkins W.T., Westgate J.A., Gorton M.P., Jackson S.E., Neal C.R. and Chenery S.P. (1997) A compilation of new and published major and trace element data for NIST SRM 610 and NIST SRM 612 glass reference materials. Geostandards Newsletter 21, 115-144.

Peterson C.H. and Beal B.F. (1989) Bivalve growth and higher order interactions: importance of density, site, and time. Ecology 70, $1390-1404$.

Pratt D.M. (1953) Abundance and growth of Venus mercenaria and Calocardia morrhuana in relation to the character of bottom sediments. Journal of Marine Research 12, 60-74.

Pratt D.M. and Campbell D.A. (1956) Environmental factors affecting growth in Venus mercenaria. Limnology and Oceanography 1, 2-17.

Reise K. (1998) Pacific oysters invade mussel beds in the European Wadden Sea. Senckenbergiana Maritima 28, 167-175.

Rhoads D.C. and Lutz R.A. (1980) Skeletal growth of aquatic organisms. New York, NY: Plenum Press.

Richardson C.A. (2001) Molluscs as archives of environmental change. Oceanography and Marine Biology 39, 103-164.

Schnack J.E., Fasano J.L. and Isla F.I. (1982) The evolution of Mar Chiquita lagoon, Province of Buenos Aires, Argentina. In Colquhoun D.J. (ed.) Holocene sea-level fluctuations: magnitudes and causes. Columbia: IGCP 61, University of South Carolina, pp. 143155 . 
Schöne B.R., Zhang Z., Radermacher P., Thébault J., Jacob D.E., Nunn E.V. and Maurer A.F. (2011) $\mathrm{Sr} / \mathrm{Ca}$ and $\mathrm{Mg} / \mathrm{Ca}$ ratios of ontogenetic ally old, long-lived bivalve shells (Arctica islandica) and their function as paleotemperature proxies. Palaeogeography, Palaeoclimatology, Palaeoecology 302, 52-64

Surge D. and Walker K.J. (2006) Geochemical variation in microstruc tural shell layers of the southern quahog (Mercenaria campechiensis) implications for reconstructing seasonality. Palaeogeography, Palaeoclimatology, Palaeoecology 237, 182-190.

Taskinen J. (1998) Influence of trematode parasitism on the growth of a bivalve host in the field. International Journal for Parasitology 28 , 599-602.

Urban J.H. (1998) Description and management of a clam fishery (Gari solida, Psammobiidae) from Bahía Independencia, Peru $\left(14^{\circ} \mathrm{S}\right)$ Fisheries Research 35, 199-207.

Viégas O. (1982) Crescimento e produção de Tagelus plebeius (Solecurtidae: Bivalvia) no Canal do Calunga, Maceió, Alagoas. Atlântica 5, 124-125.
Vincent B., Joly D. and Harvey M. (1994) Spatial variation in growth of the bivalve Macoma balthica (L.) on a tidal flat: effects of environmental factors and intraspecific competition. Journal of Experimental Marine Biology and Ecology 181, 223-238.

Weinberg J.R. (1998) Density-dependent growth in the Atlantic surfclam, Spisula solidissima, off the coast of the Delmarva Peninsula, USA. Marine Biology 130, 621-630.

and

Zar J.H. (1999) Biostatistical analysis, 4th edition. Englewood Cliffs, NJ: Prentice-Hall, Inc.

\section{Correspondence should be addressed to:}

B.J. Lomovasky

Laboratorio de Ecología, Instituto de Investigaciones Marinas y Costeras (IIMyC), Consejo Nacional de Investigaciones Científicas y Técnicas (CONICET), Universidad Nacional de Mar del Plata (UNMDP), CC 1260 Correo Central (B76ooWAG), Mar del Plata, Argentina email: lomovask@mdp.edu.ar 